\title{
History Analysis, Form of Presentation, and Function Tortor Naposo Nauli Bulung on Batak Mandailing Communities
}

\author{
$\underline{D i l i n a r}$ Adlin $^{1}$, Ruth Hertami Dyah Nugrahaningsih ${ }^{2}$ \\ 1,2Faculty of Languages and Arts, Medan State University, Indonesia \\ Email: dilinaradlinmpd@gmail.com
}

\begin{abstract}
Tortor Naposo Nauli Bulung is one of North Sumatra's local dance content, originating from the Mandailing Batak. As a traditional dance, this tortor has binding rules, sourced from the Dalihan Na Tolu kinship system, which illustrates the roles in it such as kahanggi, Mora, and boru children, so that the various movements contain traditional rules and norms that apply and must be obeyed when adhered to to dance it. This article discusses the history, form of presentation, and function of tortors. Theories used to explore history are the progressive-linear theory according to Ibn Khaldun, Djelantik's opinion for the form of presentation, and the theory of function according to Shay. The research method is descriptive qualitative. The results of the study conveyed Tortor Naposo Nauli Bulung became a medium for socializing. This tortor was performed by young people with six or three pairs of dancers. The floor pattern used was only two shapes, namely the horizontal line pattern and the triangle shape. The group of dancers in the front are called 'na gakspi' or 'na isembar', while the group in the back is called 'pangayapi' or 'panyembar'. The basic motions of the Naposo Nauli Bulung tortor are: a) Manyomba tu Raja, b) Markusor (spinning), and c) Singgang (squatting). Naposo Nauli Bulung Tortor contains four functions, namely: as a reflection and legitimacy of the social order, as a vehicle for secular rite expression, dance as social entertainment or recreational activities, and dance as a reflection of aesthetic values.
\end{abstract}

Keywords: tortor Naposo Nauli Bulung, history, form of presentation, function.

\section{Introduction}

Naposos Nauli Bulung Tortor is one of the Batai Mandailing ethnic dance dances. Tortor is a term for dance in the Batak language, both Mandailing Batak, Toba Batak, and Simalungun Batak. Of the five Batak tribes in North Sumatra, only Karo Batak and Pakpak Dairi Batak do not mention dance by the term tortor, but landek for the Karo Batak tribe and tatak for Pakpak Dairi Batak. The word tortor is usually used to refer to dance, if the dance is part of traditional activities related to the customs and norms of the community, which are relevant to its culture. Like to mention the tortor Naposo Nauli Bulung. This tortor is not called 'dance' because it is bound by the rules and norms of the Mandailing Batak community which in this case embodies their kinship system, namely Dalihan $\mathrm{Na}$ Tolu.

The Tortor Naposo Nauli Bulung is important for the Mandailing Batak people, because it reflects their identity to themselves and to others. Tortor Naposo Nauli Bulung, through his dance events, has a special power to represent how the Mandailing Batak people are steadfast in preserving their traditions. Through the form of presentation, we are helped to understand how they manifest their socio-cultural values, how a person interacts socially in his kinship system through his role as a dancer (panortor), the rules of motion, and the pattern of the floor. While through its function we can understand the value of the Mandailing community, expressed in the self-control of the community, which for them is considered important to maintain the identity of the kinship system. In addition, the function of dance is also used as a means to animate 
Mandailing values that continue to be used in the form of socialization of the community, as education to realize Mandailing community members who are characterized.

\section{Discussion}

\subsection{History}

History can be understood as the origin or genealogy. Etymologically, the word history comes from the Arabic 'syajaratun' which means tree. If it resembles a tree, then explaining history means explaining the complete tree to its smallest part. To understand the history of the tortor in the Mandailing Batak tribe, the role of the tortor in the activities of the Batak Mandailing community will be explained.

The Mandailing people really love, appreciate and boast their traditional arts such as traditional dance and traditional music that are full of values, as well as the norms that apply in their kinship system. Traditional dance in the Mandailing community can be divided into three forms, namely: 1) Tortor, 2) Sarama and 3) Moncak. These three forms are often performed on various occasions such as traditional ceremonies, including: marriage ceremony (Haroan Boru), death ceremony (Mambulungi), child birth ceremony (Sorang).

The meaning of literal tortor is dance. In depth, tortor is not just a physical activity moving to the rhythm, but a medium for socializing in the Mandailing community, such as the Naposo Nauli Bulung tortor, which in its implementation at various traditional ceremonies, enforces the role of the Dalihan $\mathrm{Na}$ Tolu kinship system. The movements carried out in this tortor are communication interactions that contain a sense of brotherhood and solidarity for the common good and the principle of a spirit of togetherness. Malau (2000: 215) explains "tortor is the art of dance by moving the entire body guided by the rhythm of gordang, with the center of movement in the hands and fingers, feet and soles of the feet / back and shoulders".

In the Mandailing community, tor is the name for the hill. Another source explains that the term "tortor" is thought to originate from the word "tor tu tor", which means "from one hill to the other". This word is then abbreviated to "tortor". The definition of "tor tu tor" can also mean a line that depicts a number of hills that go up and down, in the form of a number of triangles lined up, which are basically similar to one of the movements in a tortor, such as the tortor naposo nauli bulung. Dancers who are manortor (dancing tortor), their bodies look like up and down to the rhythm of gordang, and in rhythm with the movements of both hands like people who are marsomba (worship).

Another understanding of the word tortor in the Mandailing language comes from the word 'mangantor' which is a condition where a person's hands and feet are experiencing vibrations due to collide with certain objects that are hard so that it causes pain. Thus, if it is connected with the movement of the manortor, then the vibration is seen in the movements of the female panortor (dancer) who moves both hands (fingers) to the rhythm of the curtain. The movement is in tune with the sound of ogung dadaboru (female gong) on the first count and ogung male (male gong) on the third count.

Presentation Form

Djelantik (1990: 14) explains that: "Forms are the basic elements of the composition of performances. Supporting elements that help the form in achieving its distinctive manifestations are: dancers, costumes and make-up, dance presented, venue, time and audience. "Still according to Djelantik (1999: 73) said that:" Presentation is how the art is presented to the viewers, the 
audience, observers, readers, and listeners who are generally busy ". Thus, the form of presentation can be concluded to be the supporting elements of the composition of the performances which in this study include dancers, dances (movements), and costumes that are presented and presented to the audience.

In the Mandailing community there are several tortors known (Sutan Tinggi, 2013: 21), among them are: Tortor Naposo Nauli Bulung. The form of tortor presentation is related to the Mandailing community culture system which has a binding regulation. This tortor is performed by young people. The six or three pairs of dancers symbolize the Dalihan $\mathrm{Na}$ Tolu kinship system adopted by the Mandailing community. Delivered by young people gives meaning to how young people always maintain politeness in relationships, how men protect and protect women by promoting morality. Male dancers who are always behind the female dancers symbolize their determination to maintain politeness according to the teachings of religion and traditional teachings. The floor pattern used is only two shapes, namely the horizontal line pattern and the triangle shape. In the horizontal line pattern, the male dancer (panortor) group is always behind the female dancer (panortor) group. The straight-line pattern implies the strong and unwavering determination of the Mandailing youth to maintain their customary rules. In addition, horizontal straight lines formed by dancers formations suggest calm, which means they will not be affected by the hustle and bustle of modernization of their cultural heritage. The triangular floor pattern composed of three lines, in addition to symbolizing the kinship between kahanggi, boru children, and mora, can be assumed to show the close relationship between adat, religion, and art. The three of them stood respecting each other, respecting each other, and protecting each other. The triangle pattern can also be interpreted as an attitude and the nature of the Mandailing community which is full of simplicity, friendliness, and loyalty.

The group at the front is called 'na akspipi' or 'na isembar', while the group at the back is referred to as 'pangayapi' or 'panyembar'. The group at the front is a kinship group that is respected by the group at the back. Usually the group of female dancers (na isembar) have the same boru (clan), for example nassution. Whereas the male dancers in the back row (pangayapi) must have different clans from the female dancers, for example with the surname Harahap, or Lubis, or Rangkuti, and others. The rules for dancers who may not be of the same clan also show that the Mandailing people uphold the customary rules at any opportunity.

The range of motion used in this tortor is:

a. Manyomba tu Raja (respect to the king). The position of the panortor (dancer) while doing this motion is one line. The technique for doing this:

Woman : The right foot is in front of the left foot, with the knees bent slightly. Both hands are in front of the abdomen, with palms facing down and the fingers are moved to the rhythm, the body position upright and the head is subject to see the fingers.

Male : The right foot is in front of the left foot, with the knees bent slightly. The two hands in front are parallel to the shoulders, with palms facing down and fingers in accordance with the rhythm, upright body position and head down.

b. Markusor (spinning), the technique of doing it:

Female : Manerser feet (shifting slowly with the soles of the feet forming the letters ' $v$ ' closed and ' $v$ ' open) to the right until they form a circle. Both hands are on the side of the body with a grasping shape, upright body position and head slightly bent.

Men :Walking legs (mangalangka) cross to follow women's movements. Both hands are stretched diagonally at the side of the body like an ape (eagle) with palms facing up (mangayapi), upright body position and head upright. 
c. Singgang (squatting), the technique of doing this:

Woman :Both knees are bent so that the position of the body slowly drops down until the squat position is slightly down. Both hands in front of the abdomen with palms facing up and the fingers moved according to the rhythm, upright body position following the foot movements that are shaved, the head slightly bent to look at the fingers.

Men :Follow the movements of women with the hands in front of the shoulders parallel to the shoulder, palms facing up and the fingers are moved according to the rhythm, upright body position following the foot movements that are shaved, the head slightly subject.

The basic range of motion in the Naposo Nauli Bulung tortor means the following: a. Manyomba tu Raja: Signifying that the Mandailing people respect the king and respect their fellowmen.

b. Markusor (spinning): indicates that the Mandailing community holds fast to the kinship system, indicated by the position of panortors who form triangles that signify the $\mathrm{d} \mathrm{Na}$ na tolu. The position of the palm of the hand means asking for prayer to the above (God) so that in the implementation of the horja is given a blessing.

c. Singgang (squatting), signifies the humility of the Mandailing people

Clothing that is used when the manortor if connected with when carrying out traditional ceremonies, depends on what position / position carried by someone at the ceremony. In general, panortors do not wear special clothes, but the type of ulos and how to wear will show their status in the kinship system involved. If he acts as a suhut and kahanggi for men, he will wear his head and head ulos, which he will throw on his shoulders. Whereas if he acts as a woman suhut and kahanggi, then he will wear a jarunjung (a type of edit) and the location of the ulos goddess is also slung over his shoulder.

In their roles as male and female Boru, the way to wear ulos is different from the previous party by placing it on the left shoulder, while the female boru does not use jarunjung and the male boru child does not use appu on his head. If its role as the king of panusunan bulung and the kings of beam torbing, the way to wear ulos and appu is the same as those who act as suhut and kahanggi.

Compliance using ulos by male dancers and female dancers when performing Naposo Nauli Bulung tortor, expressing how strong and meaningful customs are for the Mandailing community, and always being applied in activities carried out by members of the Mandailing community. Compliance with customary rules that are instilled in the younger generation through the Naposo Nauli Bulung tortor, will shape the character of the younger generation of Mandailing people who are always obedient and are subject to truth and goodness. Attitudes that uphold the truth and goodness, are expressed in the actions of most of the young generation of the Mandailing community in socializing.

\subsection{Function} namely:

Anthony Shay (1971) explained that there were six (6) categories of dance functions,

"1) dance as a reflection and legitimacy of the social order, 2) dance as a vehicle for the expression of secular or religious rites, 3) dance as social or recreational entertainment, 4) dance as a channel or release of the psyche, 5) dance as a reflection of aesthetic values or an aesthetic activity in itself, and 6) dance as a reflection of the 
pattern of economic activity as a life support or economic activity in itself "(in Anya 2007: 85)

From the first Shay category, this study found that Naposo Nauli Bulung's tortor was a reflection and legitimacy of social order. In Naposo Nauli Bulung tortor there is legitimacy of grouping based on sexuality in which female panortors do not mix and are always in front of male panortors. This grouping shows how the Mandailing community respects the teachings of religion and the identity of themselves and others; age grouping can be seen from the category of young people who dance this tortor. The grouping on this element shows how ethical and orderly education of the kinship system begins to be taught to the younger generation who will continue and maintain their own customs; kinship grouping is manifested in the rule that female panortors may not be of the same age as male panortors, it is expected that female panortors are children of male panortor bone boru, according to the rules in Dalihan $\mathrm{Na}$ Tolu, the kinship system of the Batak Mandailing community. In this section, rules for adhering to the upright clan system are established, because the clan system maintains the customs of the Mandailing people.

From the second category of Shay, it can be seen that the Naposo Nauli Bulung tortor is a vehicle for expression of secular rites. Secular rites in this context can be understood as an act or procedure for maintaining the Dalihan $\mathrm{Na}$ Tolu institution through the Naposo Nauli Bulung tortor, separate from religious activities adhered to by the Mandailing community. The implementation of the secular rite is reflected in the implementation of the Naposo Nauli Bulung tortor which is related to the cultural system of the Mandailing community, which has binding rules. Tortor Naposo Nauli Bulung is involved in traditional ceremonies such as marriage, entering a new home and the birth of a child. In this activity, tortor becomes an inseparable cultural device. The role of the Naposo Nauli Bulung tortor in the traditional activities above is not just a mere performance, but a dance event that binds the traditional activity. In this case, it appears that customary activities can take place because of the presence of Naposo Nauli Bulung tortor.

In accordance with the third Shay category, which serves to provide entertainment or recreation, the Naposo Nauli Bulung tortor performance either as a traditional activity or separated from traditional activities, both put the Naposo Nauli Bulung tortor as entertainment, because all those present in the activity enjoyed the Naposo Nauli Bulung tortor performance. . Its simple movements and not too difficult to learn make Naposo Nauli Bulung's tortor a fun dance but still respectable and elegant. Through its function as entertainment, tortor Naposo Nauli Bulung carries a message that the young people of the Mandailing community continue to maintain and preserve this dance, and continue to present it at any artistic opportunity. In the fourth function according to the Shay category, namely dance as a channel or psychiatric release, tortor Naposo Nauli Bulung does not show its function as a representative. However, according to its definition, as an expression of the soul, the dancer or panortor tortor Naposo Nauli Bulung uses the dance (tortor) as a channel to express the soul of the younger generation of the Mandailing people in respecting and respecting applicable and binding customs. This situation confirms that the task of panortors in understanding the psychiatric release channel means understanding the message contained in Naposo Nauli Bulung's tortor, then expressing it when acting.

The fifth function of dance in Shay's typology is that dance is an aesthetic activity. Aesthetic activities here are understood as an activity that expresses the value of beauty. Although the dance movements in the Naposo Nauli Bulung tortor are fairly simple and consist of only three kinds of movements, the value of the beauty that the tortor wishes to show remains 
conveyed. The simplicity of the repetitive motion and obediently expressed in the rules of doing so precisely sharpens the value of the contained beauty, which it wishes to convey to the audience. Thus, understanding the value of beauty in dance is not merely seeing movement that is loaded with pure or meaningful movements that have been distorted and distorted, but rather at depth the meaning stored in the motion.

The Mandailing Batak community, through the Naposo Nauli Bulung tortor tradition, has an important aesthetic value framework delivered. Described in the assessment of what is considered good and what is considered bad and why. As part of an adat activity, tortor Naposo Nauli Bulung has rules for what is considered good for his panortors, one of which is that between female and male panortors may not be of the same sex. Contrary to this rule means doing something that is considered bad by members of the community. Another thing that raises good principles is channeled through the rule that male panortors must always be behind female panortors. This pattern shows how men protect women.

The sixth function of Shay's typology is not found in the Naposo Nauli Bulung tortor, namely dance as a reflection of economic activity patterns as a support for life or economic activity in itself. In accordance with the purpose of the Naposo Nauli Bulung tortor performance as part of traditional activities, the function as an economic life support is not fulfilled. This is at once a proof, that not all the content or parts of the theory conveyed by experts, can be fulfilled through community dance.

\section{Conclusion}

From all the descriptions given above, about the implementation of Naposo Nauli Bulung tortor, several conclusions can be drawn, namely:

1. The meaning of literal tortor is dance. Tortor is not only physical activity moves to the rhythm, but is a medium for socializing, such as tortor Naposo Nauli Bulung.

2. Presentation Form:

a. This tortor is related to the cultural system of the Mandailing community which has binding rules. This tortor is performed by young people. The six or three pairs of dancers symbolize the Dalihan Na Tolu kinship system adopted by the Mandailing community.

b. The floor pattern used is only two shapes, namely the horizontal line pattern and the triangle shape. In the horizontal line pattern, the male dancer (panortor) group is always behind the female dancer (panortor) group.

c. The group at the front is a kinship group that is respected by the group at the back. Usually a group of female dancers (na isembar) have the same boru (clan), for example Nasution. Whereas the male dancers in the back row (pangayapi) must have different clans from the female dancers, for example with the surname Harahap, or Lubis, or Rangkuti, and others.

d. The basic motions of the Naposo Nauli Bulung tortor are: a) Manyomba tu Raja, b) Markusor (spinning), and c) Singgang (squatting).

3. Relating to its function, the Naposo Nauli Bulung tortor contains four functions, namely: as a reflection and legitimacy of the social order, as a vehicle for the expression of secular rites, dance as social entertainment or recreational activities, and dance as a reflection of aesthetic values. 


\section{Reference}

Anya, Peterson Royce. (2007). Anthropology of Dance (trans. FX. Widaryanto). Bandung: Sunan Ambu Publisher.

Djelantik, AAM. (1990). Introduction to Aesthetic Markets. Denpasar: STSI Denpasar.

Sutan Tinggi, Ch. (2013). Regional Arts in South Tapanuli Bahagian. Medan: Partner Publishers.

Clark, R. \& Mayer, R.E. (2003). Teaching and the web: principles from e-Learning and the science of instruction.

Conrad, K. \& TrainingLinks. (2000). Instructionaldesign for web-based training. Amherst: HRD Press.

Ceriati, 2016, Pengemasan Tari Gubang berbasis Audio Visual bagi Siswa Klas X di Sekola Menengah Kejuruan (SMK) Negeri 4 Tanjungbalai, skripsi S-1 Sendrtasik Unimed.

Clifford, M. \& Wilson, M. (2000). Contextual teaching, professional learning, and student experiences: lesson learned from implementation.

Jazuli, M. (2016). Model Pembelajaran Tari Pendidikan Pada Siswa SD/MI Semarang. Pada jurnal www. academia.edu. Diunduh pada tanggal 31 Mei 2017

Komalasari, Heni. (2009). Aplikasi Model Pembelajaran Tari Pendidikan di SDN Nilem Bandung. Pada Jurnal Metodik Didaktik UPI Volume Edisi April 2009. Diunduh pada tanggal 31 Mei 2017

Rahmah,Sitti, (2015). Pengantar Pengetahuan Seni Tradisional Pakpak Dairi. Unimed Press

Rogers, E. M. (1983). Diffusion of Innovations. New York : The Free Press, A Division of Macmillan Publishing Co. Inc.

Sardiman, A.M. (2007). Interaksi dan motivasi belajar mengajar. Jakarta: Raja Grafindo Persada.

Yetti, Elindra., and Juniasih, Indah. (2016). Implementasi Model Pembelajaran Tari Pendidikan Untuk Meningkatkan Kecerdasan Kinestetik Anak Usia Dini Melalui Metode Pembelajaran Aktif (Pengembangan Model di Taman Kanak-kanak Labschool Jakarta pada Kelompok. B). Pada jurnal Pendidikan Usia Dini Volume 10 Edisi 2, November 2016. Diunduh pada tanggal 31 Mei 2017. 